Western Washington University

Western CEDAR

$8-1993$

\title{
Evolution of the Naticid Gastropod Predator-Prey System: An Evaluation of the Hypothesis of Escalation
}

Patricia H. Kelley

Thor A. Hansen

Western Washington University, thor.hansen@wwu.edu

Follow this and additional works at: https://cedar.wwu.edu/geology_facpubs

Part of the Geology Commons

\section{Recommended Citation}

Kelley, Patricia H. and Hansen, Thor A., "Evolution of the Naticid Gastropod Predator-Prey System: An Evaluation of the Hypothesis of Escalation" (1993). Geology Faculty Publications. 3.

https://cedar.wwu.edu/geology_facpubs/3 


\title{
Evolution of the Naticid Gastropod Predator-Prey System: An Evaluation of the Hypothesis of Escalation
}

\author{
PATRICIA H. KELLEY \\ Department of Geology and Geological Engineering, University of North Dakota, \\ Grand Forks, ND 58202 \\ THOR A. HANSEN \\ Department of Geology, Western Washington University, Bellingham, WA 98225
}

PALAIOS, 1993, V. 8, p. 358-375

Previous work has suggested that escalation may have characterized the history of the naticid gastropod predator-prey system, based on apparent increases in drilling frequencies and the occurrence of antipredatory aptations among prey. We evaluate this hypothesis based on a comprehensive survey (over 40,000 specimens) of predation on molluscs from the Upper Cretaceous through lower Oligocene formations within the U.S. Gulf and Atlantic Coastal Plain.

Patterns in drilling of both bivalve and gastropod prey are complex. Drilling frequencies were relatively low in the Cretaceous but increased sharply above the Cretaceous-Tertiary boundary, remaining high until the late Eocene. Following a significant decline near the EoceneOligocene boundary, drilling frequencies increased to a moderate level in the Oligocene. Contrary to our prediction based on the hypothesis of escalation, no temporal trend of increasing stereotypy of drillhole site occurred. However, significant increases in prey effectiveness (indicated by the incidence of incomplete drillholes and multiply bored shells) occurred between the Cretaceous and Oligocene. This pattern characterizes entire faunas as well as individual prey taxa that were consistently heavily drilled (turritellid gastropods and corbulid bivalves).

\section{INTRODUCTION}

The relative importance of biotic and abiotic factors in evolution has been the subject of much debate in evolutionary biology (see Ross and Allmon, 1990). Changes in the physical environment have long been recognized as agents of natural selection. In recent years, however, biotic factors increasingly have been viewed as important in evolution (Van Valen, 1973; Vermeij, 1987). Predation and competition are major biologic hazards to which species respond, either by migration, extinction, or adaptation. Interactions among competitors or between predator and prey may provide significant input into the evolutionary process.

Vermeij (1987) has hypothesized that a dominant theme of evolution during the Phanerozoic has been escalation, involving adaptation to enemies. Adaptation by one species tends to have a deleterious effect on other species within that effective environment; therefore, species must adapt simply to "stay in the same place" (Van Valen's "Red Queen hypothesis," 1973). As a result, Vermeij (1987, p. 4) has suggested, "the history of life is characterized by two simultaneous trends: increasing risks to individuals from potential enemies and increasing incidence and expression of aptations to cope with these risks. Modern organisms may be no better adapted to their biological surroundings than ancient ones were to theirs, but the biological surroundings have themselves become more rigorous within a given habitat." The idea that biologic hazards have become increasingly severe, while aptations to such hazards have become better expressed, has been referred to by Vermeij as the "hypothesis of escalation."

This hypothesis was criticized by Kitchell $(1990$, p. 154), who claimed "it emphasizes the expectation of progressive or linear trends in aptations and hazards and omits any explicit consideration of the consequences of tradeoffs or feedback," and that it assumes a constant adaptive "value" for a given trait. These criticisms appear to be unfounded; Vermeij (1987) extensively discussed adaptive tradeoffs and indicated that there need not be a tight correspondence between the expression of a trait and the functional demands placed on it. Nevertheless, the hypothesis of escalation remains controversial. Vermeij (1987) discussed 
possible arguments against this hypothesis, including: 1) nonbiological factors may be more important agents of natural selection than are biological factors; 2) adaptation may be prevented by such factors as genetic or developmental constraints and tradeoffs among aptations; and, 3) selection at the level of the individual might be opposed to or less important than selection at other levels.

The purpose of the present study is to examine the history of a particular predator-prey system, that of drilling naticid gastropods and their molluscan prey, and to apply these results to evaluating the hypothesis of escalation. We have undertaken a comprehensive survey of naticid predation from 14 stratigraphic levels within the Cretaceous and Paleogene of the U.S. Gulf and Atlantic Coastal Plain. More than 40,000 specimens have been examined in this survey, most from bulk samples.

\section{THE PREDATOR-PREY SYSTEM}

The Naticidae are one of several families of shell-drilling, predatory gastropods. Naticids, which are shallow infaunal snails, have been a major source of molluscan mortality since the Cretaceous (Sohl, 1969). As summarized by Carriker (1981), prey are enveloped within the predator's large mesopodium and oriented in a preferred position for drilling. Drilling, using the radula and secretions of the accessory boring organ, may take several hours to days. Ingestion is by means of the proboscis, which is inserted through the drill hole.

Studies of extant naticids (Kitchell, 1986; Boggs et al., 1984 ) indicate that drilling behavior is highly stereotyped in that prey are not evaluated based on experiences of individual naticids; predator behavior involves long-term responses developed over evolutionary time. Because of this, it is possible to study naticid behavior using timeaveraged fossil assemblages (Kitchell, 1986). Stereotyped behavior of extant naticids includes selectivity of drillhole site, prey size, and prey species. Such selectivity maximizes energy gain per foraging time: prey selection in laboratory trials was predictable by cost-benefit modelling (Kitchell et al., 1981). Cost to the predator is determined by drilling time, which is controlled by prey shell thickness. Benefit is a function of biomass, which is highly correlated with the internal volume of the shell. Within a prey species, the cost: benefit (thickness: internal volume) ratio generally decreases with increasing prey size. Predators choose prey items with the lowest cost: benefit ratio in a size range that can be handled.

A plausible hypothesis is that escalation may have occurred within the naticid predator-prey system over geologic time. Naticids might be expected to have improved predatory capabilities for several possible reasons: 1) in response to prey through coevolution, which is the evolution of two species in response to one another (see DeAngelis et al., in press); 2) due to competition between naticid predators (Vermeij, 1987); or, 3) by predation on the predator itself (Vermeij, 1983). In the case of naticids, which are cannibalistic, potential naticid prey are also potential predators and competitors. Increased predator ef- fectiveness would be especially favored under such circumstances. In addition, since naticids select prey based on morphology, rather than at random, it might be expected that prey would respond by evolving antipredatory morphologic aptations.

Some previous work supports the hypothesis of escalation for the naticid predator-prey system. Allmon et al. (1990) found that drilling frequencies were significantly lower for Cretaceous species of turritelline gastropods than for Paleocene, Miocene, or Plio-Pleistocene species. Data cited by Vermeij (1987) suggest that drilling frequencies for molluscs were low during the Cretaceous but may have reached modern levels by the Eocene (see also Dudley and Vermeij, 1978; Vermeij et al., 1980). Thus, the biological hazard of naticid predation appears to have become more severe, at least from the Cretaceous to sometime in the Paleogene. However, assessment of trends in drilling frequencies based on previous studies is difficult. The data presented by Vermeij include only two data points for Cretaceous through Paleocene gastropod assemblages, and only one point for bivalves. Allmon et al. (1990) also noted the inadequacy of available Cretaceous data sets.

In addition to possible increases in the frequency of drilling, naticids may have become more efficient predators through time. Previous studies indicate that drillhole position may have been more variable in the Cretaceous and Paleogene than in the Neogene (compare studies of Adegoke and Tevesz, 1974; and Kitchell, 1986, with those of Berg and Nishenko, 1975; Hoffman and Martinell, 1984; and Kelley, 1988, 1991, among others). Adegoke and Tevesz (1974) also reported a lack of prey size selectivity in an Eocene assemblage from Nigeria, while Neogene samples generally show size selectivity (Kitchell et al., 1981; Kelley, 1988, 1991; Hoffman and Martinell, 1984; Kabat and Kohn, 1986). In addition, mean size of species of three naticid genera apparently increased during the Cenozoic (Kitchell, 1986). Because larger predators are able to attack larger prey, such size change would have increased the hazard of naticid predation.

Vermeij (1987) argued that, in response to increased hazards of predation, antipredatory aptations have become more pronounced. For instance, global surveys suggest an increase in the frequency of mobile or well-armored gastropods and of bivalves with tight valve closure through geologic time (Vermeij, 1987). In addition to the global surveys, evidence of increased antipredatory aptations exists for individual lineages (Kelley, 1989). Thickness increases were documented within five common Chesapeake Group bivalve genera, apparently in response to naticid predation during the middle Miocene. Such thickness increases effectively deterred predation, as drilling frequencies within a taxon decreased as shell thickness increased.

Although studies of naticid predation exist for assemblages representing a variety of ages and paleoenvironments, the history of naticid predation cannot be reconstructed from the published literature. As Vermeij (1987, p. 423) stressed, "the hypothesis of escalation can be evaluated properly only in temporal comparisons of similar nonbiological environments." In addition, previous studies 
TABLE 1-Stratigraphic levels employed in the study. Formations and members are listed in descending stratigraphic order.

\begin{tabular}{lll}
\hline \hline \multicolumn{1}{c}{ Formation } & \multicolumn{1}{c}{ Age } & Locality \\
\hline Byram & Early Oligocene & Mississippi \\
Mint Spring & Early Oligocene & Mississippi \\
Red Bluff & Early Oligocene & Mississippi \\
Moodys Branch & Late Eocene & Louisiana, Mississippi \\
Gosport & Late middle Eocene & Alabama \\
Cook Mountain* & Late middle Eocene & Texas, Louisiana \\
Upper Lisbon* & Late middle Eocene & Alabama \\
Piney Point* & Late middle Eocene & Virginia \\
Bashi** & Early Eocene & Alabama \\
Bells Landing** & Late Paleocene & Alabama \\
Matthews Landing** & Middle Paleocene & Alabama \\
Brightseat & Early Paleocene & Maryland \\
Kincaid & Early Paleocene & Texas \\
Corsicana & Late Cretaceous & Texas \\
Providence & Late Cretaceous & Georgia \\
Ripley & Late Cretaceous & Georgia \\
\hline
\end{tabular}

* The Cook Mountain, Upper Lisbon and Piney Point Formations are roughly synchronous and are referred to in the text as the "Cook Mountain level."

** Bashi, Bells Landing, and Matthews Landing are members of the Hatchetigbee, Tuscahoma, and Naheola Formations respectively.

vary greatly in the methods used and types of data reported. Many were conducted prior to the development of an appropriate model of naticid predation (Kitchell et al., 1981), producing enigmatic and sometimes contradictory results.

To circumvent these problems, we have conducted a comprehensive, systematic study of the naticid gastropod predator-prey system in the U.S. Gulf and Atlantic Coastal Plain. If the hypothesis of escalation is valid, naticid predator-prey interactions may have differed early in the history of the group compared to later. We investigate this idea by a historical approach, concentrating on the largely unstudied (and putatively critical) early history of naticid predation (Cretaceous and Paleogene). Following Vermeij's suggestion, our data are from "similar nonbiological environments" represented by a temporal succession of 14 stratigraphic levels. This comprehensive survey allows direct comparison of predation on different-aged assemblages and testing of hypotheses on the history of predation.

\section{MATERIALS AND METHODS}

\section{Materials}

Our samples were derived from 16 formations comprising 14 stratigraphic levels (single formations or, in the case of the Cook Mountain level, 3 roughly contemporaneous formations, the Piney Point, upper Lisbon, and Cook Mountain) within the Atlantic and Gulf Coastal Plain, ranging from the Upper Cretaceous Ripley Formation to the Oligocene Byram Formation (Table 1). Collections from the Ripley and Providence Formations, housed at the U.S.G.S. in Reston, Virginia, were made available by Norman Sohl. The sample of the Matthews Landing Member of the Naheola Formation was provided by L.W. Ward of the Virginia Museum of Natural History. All other samples were collected by the authors. Those from the Brightseat Formation are housed at the U.S. National Museum; samples from the remaining units are at Western Washington University.

The assemblages were composed almost entirely of molluscs, mostly bivalves and gastropods. In all samples, the original shell material was preserved, and there was no evidence of chemical dissolution. The species diversities of the samples are generally high and the shells display no physical evidence of taphonomic alteration, such as shell wear or size sorting.

All of the collections from the Brightseat Formation and stratigraphically higher units were preserved well enough to wet sieve and treat with the following process. After a small bulk sample was washed and dried, all shells were picked, identified (using the taxonomy of Palmer and Brann, 1965, 1966, with modifications and additions from Bretsky, 1976; Dockery, 1977, 1982; MacNeil and Dockery, 1984; and Stephenson, 1941) and counted, thereby preserving the relative abundances of species. Of this sample, only those specimens that were relatively complete were observed and counted for naticid predation. Shell recovery was good for samples in the Brightseat and above, and we believe that the natural relative abundances, albeit timeaveraged, of most species were well represented in our washed collections with the exception of some large, thinshelled species, e.g., some species of Tellinidae. These sam- 
ples thus provide valuable information on overall drilling rates and prey preferences of naticids through time and in different assemblages.

Shells from the Kincaid and Corsicana Formations were not sufficiently well preserved to wash through sieves, so they were carefully cleaned with needles, leaving them exposed on matrix pedestals. Only the exterior or interior of each bivalve valve and only one face of a gastropod could be observed. Therefore only bivalve exteriors were counted for drilling frequencies, because gastropods could not be exposed sufficiently to ensure complete observation of the shell, and examination of bivalve interiors would not reveal incomplete drills or drillhole morphology.

The Ripley and Providence specimens were from collections that had been made over many years by Norman Sohl and others. Therefore these collections represent unusually complete species assemblages, but we cannot be confident that the relative abundance of each species has been maintained. For these samples, overall drilling frequencies are susceptible to bias, but drilling frequencies within species should be accurate.

Most of the data points represent two or more stratigraphically separate samples from each formation, taken at the same locality, which were then combined to provide an average for that formation. The Cook Mountain and Moodys Branch levels were much more widely sampled, including a broad spectrum of lithologies, biofacies, and regions. These samples therefore provide an average based on a much wider collection. Analysis of variations within these levels provides an important indicator of the range of drilling frequencies found at one time under different environmental circumstances (Hansen and Kelley, in prep.).

All of the sampled formations represent normal marine, inner to middle shelf, clastic sedimentary environments. Grain size varies from silty clay to glauconitic sand. The shallowest water samples represent inner shelf, sandy environments well below normal wave base. The deepest water samples represent middle shelf muddy environments (the Cretaceous Corsicana Formation represents a somewhat deeper mid-outer shelf environment). In general the climate varied from warm temperate to subtropical (Wolfe and Poore, 1982).

\section{Data Tabulation}

Drilling frequencies were tabulated for each bivalve and gastropod taxon within each stratigraphic level. Drilling frequency was defined as $\mathrm{D} / \mathrm{N}$ for gastropods and $2 \mathrm{D} / \mathrm{N}$ for bivalves, where $D=$ number of successfully drilled specimens and $\mathrm{N}=$ total number of specimens; "specimen" signifies a single valve in the case of bivalves. In the same way, overall drilling frequencies were calculated for the total bivalve and gastropod faunas of each level. Two additional measures of predation intensity were determined for each level: 1) the percent of species successfully drilled; and, 2) the percent of abundant species with drilling frequencies greater than 0.10 . The latter method was used by Vermeij (1987) as a measure of predation intensity; following his convention, we define an abundant species as one with at least 10 specimens (20 valves, in the case of bivalves).

Data on drillhole morphology and position were tabulated for each drilled specimen. Drillhole shape indicates whether the predator was a naticid or muricid gastropod. Naticid drillholes characteristically are bevelled, and parabolic in cross section; muricid drillholes are unbevelled and possess straight sides. This study focusses on predation by naticids. Drillhole site on bivalves was recorded with respect to a nine-sector grid previously used by Kelley (1988, fig. 1). Drillhole site was recorded for gastropods as well, but we have not yet analyzed these data for stereotypy. In addition, we recorded whether each hole was complete (entirely penetrating the shell) or incomplete, indicating an unsuccessful predation attempt. We did not recognize complete but nonfunctional drillholes. Such holes have inner: outer borehole diameter ratios less than about 0.5 (Kitchell et al., 1986), indicating that the inner diameter was not enlarged enough to allow passage of the proboscis. Because of the magnitude of the study, it was impractical to measure borehole diameters.

\section{RESULTS}

\section{Spatial and Environmental Patterns in Drilling Frequencies}

Little is known about the environmental variability of naticid predation in modern oceans. Drilling frequencies from all sources (including non-naticid drillers) seem to be higher in the tropics than in temperate regions (Vermeij, 1987; though Vermeij et al., 1989, present evidence for a possible reversed latitudinal gradient of drilling on bivalves). There is some evidence that drilling frequency increases with water depth (Sander and Lalli, 1982). Drilling predation from all sources varies considerably in a region, from 5 to $38 \%$ of the fauna (Vermeij, 1987).

Studies on the geographic and environmental variability of naticid drilling in fossil assemblages are virtually nonexistent. Typically, data on fossil drilling frequencies represent a sample from one locality, not reflecting possible environmental variations. An exception is the study by Allmon et al. (1990), which examined roughly contemporaneous populations of Turritella from Virginia and Alabama. In this case the Virginia specimens of Turritella were found to have higher drilling frequencies, contrary to the modern latitudinal trend. It is important to assess how variable drilling frequency can be at one time in order to evaluate the significance of observed temporal trends.

Compared to the other stratigraphic levels in our study, the Cook Mountain and Moodys Branch levels represent the largest sample size and the broadest spectrum of environments. The Cook Mountain level includes samples from the sandy mud of the Piney Point Formation in Virginia, muddy sand of the upper Lisbon Formation of Alabama, and the mostly mud Cook Mountain Formation of Louisiana and Texas. Frequency of drilling for bivalves and gastropods (combined) from individual assemblages of the Cook Mountain level varies from $7-39 \%$, with a 
mean of $21 \%$. This level spans a greater latitudinal and climatic range than does any other level in our study (warm temperate to subtropical). But although there is appreciable environmental variation within this level, drilling frequency shows no direct correlation with these variables. Drilling frequency does not correlate with sediment size, distance from shore, percentage of bivalves, or percentage of naticids (Hansen and Kelley, in prep.).

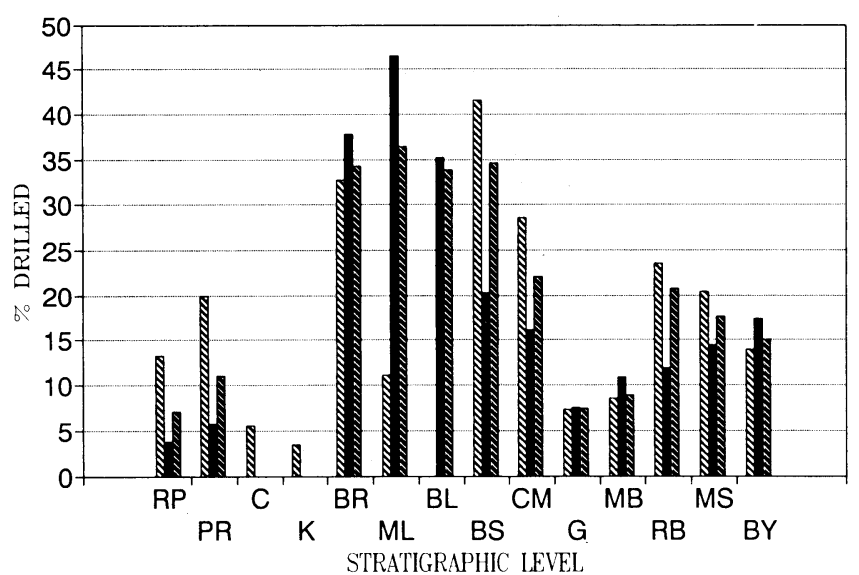

BIVALVES

GASTROPODS

\section{TOTAL}

FIGURE 1-Drilling frequencies through time for bivalves, gastropods, and total fauna. Abbreviations for stratigraphic levels: RP, Ripley; PR, Providence; C, Corsicana; K, Kincaid; BR, Brightseat; ML, Matthews Landing; BL, Bells Landing; BS, Bashi; CM, Cook Mountain; G, Gosport; MB, Moodys Branch; RB, Red Bluff; MS, Mint Spring; BY, Byram. Axis not scaled to indicate the stratigraphic spacing of levels.
The Moodys Branch Formation has no appreciable latitudinal range, but does include a variety of sedimentary facies, from shelly glauconitic sand to mostly mud. Drilling frequencies for the Moodys Branch level range from 4$22 \%$, with a mean of $10 \%$. The sample containing $22 \%$ drilled individuals is somewhat anomalous; all other samples have drilling frequencies less than or equal to $13 \%$. As in the case of the Cook Mountain level, drilling frequency in the Moodys Branch does not correlate with sediment size or distance from shore.

The wide range of drilling frequencies found within one stratigraphic level suggests that predation rates from small or geographically restricted samples must be regarded as minimum values.

\section{Temporal Patterns in Drilling Frequencies}

Vermeij (1987) suggested that a temporal increase in drilling frequencies would indicate intensification of the hazard of predation and thus escalation. His global compilations suggest that drilling frequencies were low during the Cretaceous, reaching modern levels by the Eocene. The reality and timing of such an increase has been controversial (Allmon et al., 1990).

Our data indicate that naticid predation on bivalves and gastropods combined was fairly low for Upper Cretaceous samples and rose abruptly in the middle Danian (Paleocene) samples to essentially modern levels (over $30 \%$, Fig. 1). Extremely low levels of predation occur in both the uppermost Cretaceous Corsicana and lowermost Paleocene Kincaid Formations, but these data points are somewhat suspect because of low sample sizes and relatively poor preservation. High predation levels were maintained

TABLE 2-Numbers of species (sp.) and specimens (spec.), drilling frequency (dr. freq. $=2 \times$ number of successfully drilled specimens: total number of specimens), and percent of species successfully drilled (\% sp. dr.) for all bivalve species and infaunal bivalve species within each formation. Also shown is the percent of abundant bivalve species (i.e., those with more than 20 specimens) that had drilling frequency $>0.10$ (\% ab. sp. dr.).

\begin{tabular}{|c|c|c|c|c|c|c|c|c|c|}
\hline \multirow[b]{2}{*}{ Level } & \multicolumn{5}{|c|}{ All species } & \multicolumn{4}{|c|}{ Infaunal species } \\
\hline & $\begin{array}{l}\text { \# of } \\
\text { sp. }\end{array}$ & $\begin{array}{l}\text { \# of } \\
\text { spec. }\end{array}$ & $\begin{array}{l}\text { Dr. } \\
\text { freq. }\end{array}$ & $\begin{array}{c}\% \text { Sp. } \\
\text { dr. }\end{array}$ & $\begin{array}{l}\% \text { Ab. } \\
\text { sp. dr. }\end{array}$ & $\begin{array}{l}\text { \# of } \\
\text { sp. }\end{array}$ & $\begin{array}{l}\text { \# of } \\
\text { spec. }\end{array}$ & $\begin{array}{l}\text { Dr. } \\
\text { freq. }\end{array}$ & $\begin{array}{c}\text { \% Sp. } \\
\text { dr. }\end{array}$ \\
\hline Ripley & 18 & 2629 & 0.132 & 72.2 & 61.6 & 17 & 2211 & 0.156 & 70.6 \\
\hline Providence & 19 & 639 & 0.194 & 52.6 & 83.3 & 19 & 639 & 0.194 & 52.6 \\
\hline Corsicana & 37 & 291 & 0.055 & 16.2 & 0 & 26 & 209 & 0.077 & 23.1 \\
\hline Kincaid & 43 & 1054 & 0.034 & 18.6 & 7.7 & 38 & 855 & 0.042 & 21.0 \\
\hline Brightseat & 45 & 1743 & 0.327 & 37.8 & 81.8 & 40 & 1635 & 0.347 & 40.0 \\
\hline Matthews Landing & 8 & 235 & 0.111 & 62.5 & 33.3 & 7 & 210 & 0.124 & 71.4 \\
\hline Bells Landing & 15 & 62 & 0 & 0 & - & 13 & 42 & 0 & 0 \\
\hline Bashi & 13 & 1124 & 0.415 & 61.5 & 100.0 & 13 & 1124 & 0.415 & 61.5 \\
\hline Cook Mountain & 90 & 5035 & 0.287 & 46.7 & 74.2 & 75 & 4627 & 0.289 & 52.0 \\
\hline Gosport & 30 & 468 & 0.073 & 23.3 & 20.0 & 25 & 454 & 0.070 & 24.0 \\
\hline Moodys Branch & 54 & 13,372 & 0.086 & 63.0 & 36.7 & 50 & 12,881 & 0.089 & 62.0 \\
\hline Red Bluff & 31 & 2197 & 0.235 & 19.4 & 50.0 & 23 & 2031 & 0.254 & 26.0 \\
\hline Mint Spring & 38 & 1596 & 0.204 & 57.9 & 76.9 & 31 & 1505 & 0.210 & 64.5 \\
\hline Byram & 20 & 662 & 0.139 & 45.0 & 100.0 & 18 & 654 & 0.141 & 50.0 \\
\hline
\end{tabular}


through the Paleocene and early to middle Eocene and then dropped abruptly to Cretaceous levels in the late middle and late Eocene. Predation rates rose again in the early Oligocene, but did not attain the high levels of the Paleocene and early Eocene.

Naticid gastropod predation on bivalves is summarized in Table 2 and Figures 1 and 2. Predation on bivalves, as indicated by all three methods of measurement (\% of individuals, species, and abundant species drilled), varied

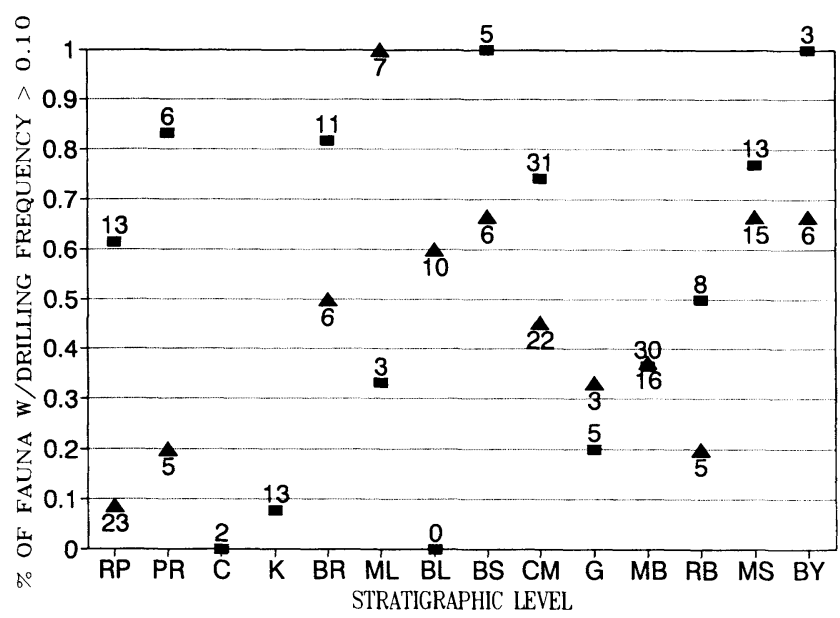

- BIVAlVes $\triangle$ Gastropods

FIGURE 2-Percent of abundant species with drilling frequencies greater than 0.10 . Abundant species are those with more than 20 valves (bivalves) or 10 specimens (gastropods). Number of species indicated above (bivalves) or below (gastropods) each data point. Abbreviations for stratigraphic levels as in Figure 1. Axis not scaled to indicate the stratigraphic spacing of levels. widely during the Cretaceous through Oligocene. Predation on the bivalve fauna as a whole closely reflects that measured for infaunal bivalves only, as infaunal species dominate all the samples.

Drilling frequency was moderately high in the Cretaceous Ripley and Providence Formations in terms of percent of bivalve individuals drilled, and very high in terms of percent of species that experienced drilling. In addition, a large percent of the abundant species in the fauna exhibited drilling frequencies greater than $10 \%$ (Table 2; Fig. 2). All measures of predation then declined significantly to very low values in the uppermost Cretaceous Corsicana Formation and lowermost Paleocene Kincaid Formation; drilling frequencies are significantly different for the Providence and Corsicana $\left(\chi^{2}=13.89, \mathrm{P}<0.001\right)$.

Bivalves from the lower Paleocene Brightseat Formation experienced relatively high predation; $33 \%$ of individuals and $38 \%$ of species were drilled, and $82 \%$ of the abundant species had drilling frequencies greater than $10 \%$. This increase is highly significant $\left(\chi^{2}=145.80\right.$ with 1 degree of freedom for a comparison of Kincaid and Brightseat drilling frequencies). Although the percent of bivalve species drilled was large in the middle Paleocene Matthews Landing level, only $11 \%$ of bivalve individuals were drilled. The uppermost Paleocene Bells Landing sample is dominated by gastropods, and none of the fifteen bivalve species present was drilled.

Drilling frequency was substantial in both the lower Eocene Bashi and middle Eocene Cook Mountain levels ( $42 \%$ and $29 \%$ for individuals, respectively). The percent of individuals drilled then dropped significantly $\left(\chi^{2}=42.12\right.$, with 1 degree of freedom), to 7-9\% in the Gosport and Moodys Branch. (In contrast, $63 \%$ of the Moodys Branch bivalve species were drilled, though at very low levels. This is probably an effect of the large sample size for the Moodys

TABLE 3-Numbers of species (sp.) and specimens (spec.), drilling frequency (dr. freq. = number of successfully drilled specimens : total number of specimens), and percent of species successfully drilled (\% sp. dr.) for all gastropod species and infaunal gastropod species within each formation. Also shown is the percent of abundant gastropod species (i.e., those with more than 10 specimens) that had drilling frequency $>0.10$ (\% ab. sp. dr.).

\begin{tabular}{|c|c|c|c|c|c|c|c|c|c|}
\hline \multirow[b]{2}{*}{ Level } & \multicolumn{5}{|c|}{ All species } & \multicolumn{4}{|c|}{ Infaunal species } \\
\hline & $\begin{array}{c}\text { \# of } \\
\text { sp. }\end{array}$ & $\begin{array}{l}\text { \# of } \\
\text { spec. }\end{array}$ & $\begin{array}{l}\text { Dr. } \\
\text { freq. }\end{array}$ & $\begin{array}{c}\text { \% Sp. } \\
\text { dr. }\end{array}$ & $\begin{array}{l}\% \text { Ab. } \\
\text { sp. dr. }\end{array}$ & $\begin{array}{l}\text { \# of } \\
\text { sp. }\end{array}$ & $\begin{array}{l}\text { \# of } \\
\text { spec. }\end{array}$ & $\begin{array}{l}\text { Dr. } \\
\text { freq. }\end{array}$ & $\begin{array}{c}\text { \% Sp. } \\
\text { dr. }\end{array}$ \\
\hline Ripley & 29 & 2426 & 0.037 & 51.7 & 8.7 & 12 & 1484 & 0.032 & 58.3 \\
\hline Providence & 11 & 516 & 0.060 & 54.5 & 20.0 & 4 & 312 & 0.083 & 100.0 \\
\hline Brightseat & 18 & 414 & 0.377 & 66.7 & 50.0 & 11 & 275 & 0.484 & 72.7 \\
\hline Matthews Landing & 20 & 297 & 0.465 & 50.0 & 100.0 & 5 & 181 & 0.486 & 80.0 \\
\hline Bells Landing & 26 & 742 & 0.352 & 38.5 & 60.0 & 14 & 692 & 0.366 & 50.0 \\
\hline Bashi & 32 & 271 & 0.203 & 43.8 & 66.7 & 12 & 204 & 0.191 & 50.0 \\
\hline Cook Mountain & 59 & 2761 & 0.162 & 44.1 & 45.5 & 28 & 2441 & 0.175 & 50.0 \\
\hline Gosport & 23 & 200 & 0.075 & 21.7 & 33.3 & 10 & 171 & 0.088 & 50.0 \\
\hline Moodys Branch & 46 & 938 & 0.109 & 41.3 & 37.5 & 13 & 476 & 0.099 & 61.5 \\
\hline Red Bluff & 39 & 329 & 0.119 & 23.1 & 20.0 & 13 & 172 & 0.134 & 15.4 \\
\hline Mint Spring & 51 & 737 & 0.145 & 52.9 & 66.7 & 23 & 552 & 0.111 & 56.5 \\
\hline Byram & 25 & 178 & 0.174 & 48.0 & 66.7 & 9 & 70 & 0.200 & 55.6 \\
\hline
\end{tabular}


TABLE 4-Distribution of boreholes with respect to a nine-sector grid, and results of chi-squared tests. DMV, dorsal-middle-ventral comparison; AMP, anterior-middle-posterior comparison; 9S, nine sector comparison. Italicized chi-squared values are not significant at the 0.05 level. All other values are significant at least at the 0.05 level.

\begin{tabular}{|c|c|c|c|c|c|c|c|c|c|c|c|c|c|}
\hline \multirow[b]{2}{*}{ Level } & \multirow[b]{2}{*}{ Taxon } & \multicolumn{9}{|c|}{ Sector } & \multicolumn{3}{|c|}{ Chi-squared } \\
\hline & & 1 & 2 & 3 & 4 & 5 & 6 & 7 & 8 & 9 & DMV & AMP & 9S \\
\hline \multirow[t]{4}{*}{ Ripley } & Striarca sp. & 0 & 0 & 0 & 0 & 3 & 0 & 2 & 16 & 0 & 26.6 & 31.1 & \\
\hline & Caestocorbula sp. & 1 & 6 & 1 & 2 & 17 & 3 & 0 & 1 & 0 & 22.1 & 27.2 & \\
\hline & Corbula sp. & 3 & 6 & 1 & 3 & 19 & 2 & 4 & 7 & 1 & 7.5 & 28.4 & 49.1 \\
\hline & Lucina parva & 1 & 0 & 0 & 4 & 8 & 0 & 1 & 1 & 0 & 14.8 & 8.4 & \\
\hline \multirow[t]{2}{*}{ Providence } & Striarca cuneata & 0 & 2 & 1 & 1 & 11 & 0 & 0 & 3 & 0 & 9 & 25 & \\
\hline & Corbula sp. & 0 & 2 & 0 & 1 & 7 & 3 & 3 & 5 & 2 & 6.3 & 7.9 & \\
\hline \multirow[t]{7}{*}{ Brightseat } & Pitar sp. & 0 & 5 & 1 & 2 & 7 & 0 & 0 & 0 & 0 & 8.4 & 14.8 & \\
\hline & Corbula subengonata & 0 & 4 & 2 & 3 & 5 & 0 & 2 & 3 & 1 & 0.4 & 6.7 & \\
\hline & Crassatella alaeformis & 0 & 7 & 5 & 4 & 23 & 3 & 2 & 2 & 0 & 23.1 & 27.3 & 78.4 \\
\hline & Vokesula aldrichi & 1 & 1 & 1 & 1 & 6 & 2 & 3 & 6 & 3 & 5.2 & 4.8 & \\
\hline & Venericardia planicosta & 1 & 3 & 2 & 5 & 6 & 1 & 0 & 1 & 0 & 9.6 & 3.9 & \\
\hline & Venericardia sp. & 1 & 10 & 3 & 4 & 9 & 5 & 1 & 4 & 2 & 4.8 & 12.2 & \\
\hline & Phacoides sp. & 2 & 10 & 0 & 8 & 63 & 2 & 1 & 8 & 0 & 83.3 & 119.4 & 309 \\
\hline \multirow[t]{3}{*}{ Bashi } & Venericardia horatiana & 1 & 0 & 1 & 12 & 26 & 12 & 32 & 31 & 18 & 71.4 & 7.6 & 88.6 \\
\hline & Corbula subengonata & 3 & 0 & 1 & 3 & 12 & 3 & 6 & 1 & 3 & 9.3 & 1.9 & \\
\hline & Vokesula aldrichi & 0 & 0 & 2 & 1 & 17 & 15 & 3 & 8 & 1 & 31.9 & 14.6 & 66.6 \\
\hline \multirow[t]{6}{*}{ Cook Mountain } & Lucina pomilia & 4 & 12 & 2 & 3 & 33 & 4 & 1 & 3 & 0 & 31.9 & 54.3 & 125 \\
\hline & Spisula parilis & 2 & 8 & 2 & 3 & 8 & 4 & 1 & 1 & 2 & 6.3 & 6.6 & \\
\hline & Callista perovata & 4 & 12 & 2 & 3 & 3 & 3 & 0 & 1 & 0 & 15.5 & 7.4 & \\
\hline & Caryocorbula deusseni & 1 & 2 & 2 & 4 & 4 & 3 & 1 & 6 & 2 & 2.2 & 2.5 & \\
\hline & Corbula extenuata & 1 & 2 & 0 & 3 & 9 & 9 & 2 & 6 & 1 & 15.3 & 5.6 & \\
\hline & Pachecoa decisa & 6 & 35 & 3 & 4 & 20 & 1 & 3 & 10 & 4 & 13.4 & 69.5 & 104 \\
\hline \multirow[t]{4}{*}{ Moodys Branch } & Lucina subcurta & 2 & 15 & 4 & 4 & 28 & 8 & 2 & 4 & 4 & 19.5 & 35.9 & 74.1 \\
\hline & Lucina curta & 3 & 8 & 0 & 6 & 12 & 3 & 3 & 1 & 0 & 12.2 & 13.5 & \\
\hline & Caestocorbula wailesiana & 1 & 3 & 2 & 9 & 17 & 2 & 3 & 8 & 7 & 14 & 9.9 & 36.3 \\
\hline & Spisula jacksonensis & 2 & 7 & 5 & 3 & 8 & 5 & 0 & 4 & 1 & 5.9 & 8.5 & \\
\hline \multirow[t]{3}{*}{ Red Bluff } & Scapharca invidiosa & 0 & 0 & 1 & 2 & 20 & 8 & 1 & 2 & 2 & 41.2 & 15.2 & \\
\hline & Astarte triangulata & 0 & 0 & 2 & $\overline{5}$ & 14 & 4 & 4 & 4 & 6 & 17.1 & 3.2 & \\
\hline & Corbula rufaripa & 7 & 9 & 6 & 19 & 50 & 18 & 21 & 29 & 21 & 38.2 & 19.6 & 73.7 \\
\hline Mint Spring & Corbula laqueata & 3 & 1 & 4 & 4 & 18 & 10 & 11 & 16 & 14 & 21.6 & 5.4 & 34.4 \\
\hline Byram & Corbula laqueata & 1 & 1 & 1 & 3 & 8 & 2 & 0 & 3 & 3 & 7.2 & 4.7 & \\
\hline
\end{tabular}

Branch.) Predation in the three lower Oligocene formations occurred at levels comparable to those in the Cretaceous. These values are significantly higher than those for the upper Eocene $\left(\chi^{2}=206.44\right.$, Moodys Branch and Red Bluff comparison).

Predation intensity on gastropods (Table 3, Figs. 1, 2) was low in the Cretaceous, high in the Paleocene and somewhat reduced in the Eocene and Oligocene. Although epifaunal gastropods were abundant in the samples, predation on infaunal gastropods was similar to that for the gastropod fauna as a whole.

Although about half the Cretaceous (Ripley and Providence) gastropod species were drilled, very few individuals were drilled ( $4 \%$ and $6 \%$ for the two formations), and the percent of abundant species with drilling frequencies greater than $10 \%$ was also relatively low. All measures of predation on gastropods were high in the Paleocene Brightseat, Matthews Landing, and Bells Landing. The differences are statistically significant; for instance, a comparison of Providence and Brightseat drilling frequencies produces a $\chi^{2}$ of 143.44 with 1 degree of freedom. Significantly lower drilling frequencies occurred in all the Eocene and Oligocene levels; percent of individuals drilled was less than or equal to $20 \%$. The percent of species drilled fluctuated during this interval between about 20 and $50 \%$; these values are lower than those for the lower Paleocene samples.

\section{Stereotypy of Naticid Behavior}

The dynamics of the naticid-prey system may have differed during the history of the group. If the hazard of naticid predation increased as predicted by the hypothesis of escalation, we suggest that naticid behavior may have been less stereotyped early in their history. We investigated one aspect of naticid behavioral stereotypy, drillhole 
TABLE 5-Numbers and percentages of all bivalve species, successfully drilled bivalve species, infaunal bivalve species (inf. sp.), and infaunal successfully drilled bivalve species (inf. dr. sp.) bearing incomplete and multiple holes.

\begin{tabular}{|c|c|c|c|c|c|c|c|c|c|c|}
\hline \multirow[b]{2}{*}{ Level } & \multicolumn{4}{|c|}{ All species } & \multicolumn{2}{|c|}{ Drilled sp. } & \multicolumn{2}{|c|}{ Inf. sp. } & \multicolumn{2}{|c|}{ Inf. dr. sp. } \\
\hline & $\begin{array}{l}\text { \# w/ } \\
\text { inc. }\end{array}$ & $\begin{array}{l}\text { \# w/ } \\
\text { mul. }\end{array}$ & $\begin{array}{l}\% \mathrm{w} / \\
\text { inc. }\end{array}$ & $\begin{array}{l}\% \mathrm{w} / \\
\text { mul. }\end{array}$ & $\begin{array}{c}\% \mathrm{w} / \\
\text { inc. }\end{array}$ & $\begin{array}{l}\% \mathrm{w} / \\
\text { mul. }\end{array}$ & $\begin{array}{l}\% \mathrm{w} / \\
\text { inc. }\end{array}$ & $\begin{array}{l}\% \mathrm{w} / \\
\text { mul. }\end{array}$ & $\begin{array}{l}\% \mathrm{w} / \\
\text { inc. }\end{array}$ & $\begin{array}{c}\% \mathrm{w} / \\
\text { mul. }\end{array}$ \\
\hline Ripley & 3 & 0 & 16.7 & 0 & 23.1 & 0 & 17.6 & 0 & 25.0 & 0 \\
\hline Providence & 1 & 0 & 5.3 & 0 & 10.0 & 0 & 5.3 & 0 & 10.0 & 0 \\
\hline Corsicana & 2 & 0 & 5.4 & 0 & 33.3 & 0 & 3.8 & 0 & 16.7 & 0 \\
\hline Kincaid & 1 & 1 & 2.3 & 2.3 & 12.5 & 12.5 & 2.6 & 2.6 & 12.5 & 12.5 \\
\hline Brightseat & 3 & 3 & 6.7 & 6.7 & 17.6 & 17.6 & 7.5 & 7.5 & 18.8 & 18.8 \\
\hline Matthews Landing & 3 & 1 & 37.5 & 12.5 & 60.0 & 20.0 & 42.9 & 14.3 & 60.0 & 20.0 \\
\hline Bells Landing & 1 & 0 & 6.7 & 0 & - & - & 7.7 & 0 & - & - \\
\hline Bashi & 2 & 3 & 15.3 & 23.1 & 25.0 & 37.5 & 15.4 & 23.1 & 25.0 & 37.5 \\
\hline Cook Mountain & 19 & 7 & 21.1 & 7.8 & 45.2 & 16.7 & 20.0 & 8.0 & 38.5 & 15.4 \\
\hline Gosport & 2 & 1 & 6.7 & 3.3 & 28.6 & 14.3 & 8.0 & 4.0 & 33.3 & 16.7 \\
\hline Moodys Branch & 15 & 12 & 27.8 & 22.2 & 44.1 & 35.3 & 30.0 & 24.0 & 48.4 & 38.7 \\
\hline Red Bluff & 10 & 5 & 32.3 & 16.1 & 166.7 & 83.3 & 39.1 & 17.4 & 150.0 & 66.7 \\
\hline Mint Spring & 4 & 2 & 10.5 & 5.3 & 18.2 & 9.1 & 12.9 & 6.5 & 20.0 & 10.0 \\
\hline Byram & 2 & 1 & 10.0 & 5.0 & 22.2 & 11.1 & 11.1 & 5.6 & 22.2 & 11.1 \\
\hline
\end{tabular}

site selectivity. Such selectivity promotes drilling the thinnest area of the shell (Kitchell, 1986) and correlates with greater probabilities of successful predation (Kelley, 1988). If naticids were less capable early in their history, drillhole site may be more variable for taxa from older assemblages.

Borehole distributions for all taxa were treated with two chi-squared tests. The first tested whether dorsal (sectors 1-3), middle (sectors 4-6), and ventral (sectors 7-9) areas of the shell were equally drilled. The second tested whether anterior (sectors 1, 4, and 7), middle (sectors 2, 5, and 8), and posterior (sectors 3,6 , and 9) areas of the shell were equally drilled. Eleven species had sufficient numbers of drillholes that chi-squared tests could be used to test the null hypothesis of equal drilling of each of the nine sectors.

Table 4 provides data on the distribution of drillholes for bivalve taxa from 9 of the 14 levels studied. (The other five levels contained no bivalve species drilled frequently enough to allow statistical analysis of borehole distribution.) No general temporal trend in stereotypy is apparent.

All of the six Cretaceous species in the data set showed selectivity of borehole site $(\mathrm{P}<0.05$ for all chi-squared tests). Five of the six species displayed a preponderance of boreholes in mid-valve (sector 5), while boreholes in Striarca from the Ripley Formation tended to occur in a mid-ventral position (sector 8). Somewhat less stereotypy is evident for the Paleocene Brightseat Formation. Of the seven taxa with sufficiently abundant drillholes, only three yielded significant chi-squared values for all the tests. The null hypothesis could not be rejected for Corbula subengonata and Venericardia sp. (dorsal/middle/ventral comparison), nor for Venericardia planicosta (anterior/middle/posterior comparison) or for Vokesula aldrichi (both comparisons).

Most, but not all, frequently drilled Eocene taxa showed selectivity of drillhole site. One of three Bashi species, Corbula subengonata, did not show drillhole selectivity in the anterior/middle/posterior comparison; another species, Venericardia horatiana, had a broad distribution of drillholes despite rejection of the null hypothesis. In the Cook Mountain Formation, the null hypothesis could not be rejected for Corbula extenuata (anterior/middle/posterior comparison) and Caryocorbula deusseni (both comparisons). Equal drilling of dorsal, middle, and ventral regions could not be rejected for Spisula jacksonensis of the Moodys Branch Formation.

Only four Oligocene species had sufficient numbers of drillholes for statistical analysis of their distribution. Corbula laqueata (Mint Spring and Byram Formations) and Astarte triangulata (Red Bluff) showed no anterior-toposterior preference for drilling. Boreholes were broadly distributed on Corbula rufaripa, but with a statistically significant preference for sector 5; Scapharca invidiosa was also preferentially drilled in the valve center.

\section{Relative Effectiveness of Predator and Prey}

Two types of data were used to determine whether the relative effectiveness of predator and prey changed through time: the incidence of incomplete drillholes and that of multiply drilled shells. Incomplete drillholes result from unsuccessful predation attempts; following Vermeij (1987), we used the ratio of incomplete to attempted drillholes to indicate "prey effectiveness." In addition, the presence of multiple boreholes in a shell (normally one functional hole and one or more unsuccessful holes, but sometimes multiple complete holes) may indicate successful prey escape tactics (Kitchell et al., 1986).

We considered first the percentage of species in a for- 
TABLE 6-Numbers of complete (C.D.) and incomplete (inc.) drillholes and prey effectiveness (P.E. = number of incomplete holes:total attempted holes) for bivalve species that exhibited incomplete drilling.

\begin{tabular}{|c|c|c|c|c|}
\hline Level & Species & C.D. & Inc. & P.E. \\
\hline \multirow{3}{*}{ Ripley } & Striarca sp. & 21 & 2 & 0.087 \\
\hline & Caestocorbula sp. & 31 & 2 & 0.061 \\
\hline & Corbula sp. & 46 & 6 & 0.115 \\
\hline Providence & Striarca cuneata & 14 & 1 & 0.067 \\
\hline \multirow[t]{2}{*}{ Corsicana } & Ostrea & 0 & 2 & 1.0 \\
\hline & Corbula sp. & 1 & 1 & 0.5 \\
\hline Kincaid & Saccella sp. & 0 & 1 & 1.0 \\
\hline \multirow[t]{3}{*}{ Brightseat } & Corbula subengonata & 21 & 15 & 0.417 \\
\hline & Vokesula aldrichi & 24 & 11 & 0.314 \\
\hline & Cucullaea gigantea & 5 & 1 & 0.167 \\
\hline \multirow[t]{3}{*}{ Matthews Landing } & Cucullaea macrodonta & 7 & 1 & 0.125 \\
\hline & Venericardia wilcoxensis & 2 & 1 & 0.333 \\
\hline & Corbula subcompressa & 2 & 2 & 0.5 \\
\hline Bells Landing & Vokesula aldrichi & 0 & 1 & 1.0 \\
\hline \multirow[t]{2}{*}{ Bashi } & Corbula subengonata & 32 & 7 & 0.179 \\
\hline & Vokesula aldrichi & 47 & 4 & 0.078 \\
\hline \multirow[t]{19}{*}{ Cook Mountain } & Nuculana multilineata & 3 & 1 & 0.25 \\
\hline & Saccella catasarca & 3 & 1 & 0.25 \\
\hline & Pachecoa decisa & 266 & 5 & 0.018 \\
\hline & Pachecoa declivis & 10 & 2 & 0.167 \\
\hline & Limopsis aviculoides & 12 & 1 & 0.076 \\
\hline & Chlamys clarkeana & 1 & 1 & 0.5 \\
\hline & Eburneopecten scintillatus & 0 & 1 & 1.0 \\
\hline & Cubiotstrea sellaeformis & 54 & 6 & 0.10 \\
\hline & Plicatula filamentosa & 1 & 1 & 0.5 \\
\hline & Lucina pomilia & 151 & 2 & 0.013 \\
\hline & Venericardia cf. V. alticostata & 7 & 4 & 0.364 \\
\hline & Bathytormus sp. & 5 & 2 & 0.286 \\
\hline & Spisula parilis & 32 & 2 & 0.059 \\
\hline & Pitar sp. & 2 & 1 & 0.333 \\
\hline & Anapteris regalis & 1 & 1 & 0.5 \\
\hline & Corbula cf. C. alabamiensis & 5 & 1 & 0.167 \\
\hline & Corbula extenuata & 40 & 5 & 0.111 \\
\hline & Corbula subengonata & 10 & 1 & 0.091 \\
\hline & Caryocorbula deusseni & 28 & 10 & 0.263 \\
\hline \multirow[t]{2}{*}{ Gosport } & Lyrodiscus tellinoides & 0 & 1 & 1.0 \\
\hline & cf. Caestocorbula murchisonii & 2 & 1 & 0.333 \\
\hline \multirow[t]{15}{*}{ Moodys Branch } & Nucula spheniopsis & 15 & 3 & 0.167 \\
\hline & Limopsis radiata & 5 & 5 & 0.500 \\
\hline & Lucina curta & 56 & 5 & 0.082 \\
\hline & Lucina subcurta & 100 & 4 & 0.038 \\
\hline & Venericardia diversidentata & 18 & 3 & 0.143 \\
\hline & Pleuromeris inflatior jacksonensis & 11 & 1 & 0.083 \\
\hline & Lirodiscus jacksonensis & 1 & 1 & 0.5 \\
\hline & Bathytormus flexurus & 6 & 3 & 0.333 \\
\hline & Crassinella pygmaea & 3 & 1 & 0.25 \\
\hline & Spisula jacksonensis & 37 & 4 & 0.098 \\
\hline & Alveinus minutus & 169 & 56 & 0.249 \\
\hline & Kelliella boettgeri & 31 & 15 & 0.326 \\
\hline & Callista annexa & 3 & 2 & 0.4 \\
\hline & Corbula densata & 27 & 8 & 0.229 \\
\hline & Caestocorbula wailesiana & 66 & 16 & 0.195 \\
\hline \multirow{3}{*}{ Red Bluff } & Barbatia paradigona & 0 & 1 & 1.0 \\
\hline & Scapharca $(S$.$) invidiosa$ & 36 & 3 & 0.077 \\
\hline & Limopsis sp. & 0 & 1 & 1.0 \\
\hline
\end{tabular}


TABLE 6-Continued.

\begin{tabular}{|c|c|c|c|c|}
\hline Level & Species & C.D. & Inc. & P.E. \\
\hline & Glycymeris sp. & 0 & 1 & 1.0 \\
\hline & Eburneopecten subminutus & 0 & 5 & 1.0 \\
\hline & Venericardia carsonensis & 0 & 2 & 1.0 \\
\hline & Timothynus turgida? & 3 & 1 & 0.25 \\
\hline & Astarte triangulata & 41 & 3 & 0.068 \\
\hline & Corbula (V.) rufaripa & 180 & 34 & 0.159 \\
\hline & Corbula (Caryocorbula) engonata & 3 & 9 & 0.75 \\
\hline \multirow[t]{4}{*}{ Mint Spring } & Ervilia lamelloexteria & 1 & 1 & 0.5 \\
\hline & Corbula (Caryocorbula) engonata & 14 & 5 & 0.263 \\
\hline & Corbula (Varicorbula) laqueata & 81 & 17 & 0.173 \\
\hline & Corbula rufaripa & 4 & 2 & 0.333 \\
\hline \multirow{2}{*}{ Byram } & Corbula (Caryocorbula) engonata & 1 & 1 & 0.5 \\
\hline & Corbula (Varicorbula) laqueata & 22 & 7 & 0.241 \\
\hline
\end{tabular}

mation that exhibited incomplete drillholes. Although the frequency of bivalve species with incomplete drillholes fluctuated through time, there is some evidence of a temporal increase in incomplete drilling (Table 5). With the exception of the Ripley and Matthews Landing levels, fewer than $7 \%$ of the species in the Cretaceous and Paleocene contained incomplete drillholes. In contrast, of the Eocene and Oligocene units, only in the Gosport Formation did fewer than $10 \%$ of the species contain incomplete drillholes. About $30 \%$ of the species present in the Moodys Branch and Red Bluff Formations contained incomplete drillholes. The pattern is similar, whether all bivalve prey species or only infaunal species are considered. The pattern is not simply an artifact of sample size; the correlation between number of specimens in a sample and percent of species with incomplete drillholes is nonsignificant $(r=$ $0.4306,12$ d.f.).

We also compared the number of species containing incomplete drillholes with the number of species successfully drilled for each formation. This ratio averaged 0.26 for the Cretaceous and Paleocene ( 0.19 without the Matthews Landing, which contained relatively few bivalve species) and 0.50 for the Eocene and Oligocene ( 0.31 without the Red Bluff, where ten species had incomplete drillholes but only six were successfully drilled). The pattern is similar when only infaunal bivalve prey are considered.

Table 6 lists all bivalve taxa that exhibited incomplete drilling, along with data on prey effectiveness. Sixteen infaunal families of bivalves displayed incomplete drillholes (Table 7). Prey effectiveness for each of those families (excluding 4 families with fewer than 10 total drillholes) ranged from 0.03 to 0.30 . (These values are based only on species that displayed incomplete drilling.) In particular, a large number of corbulid species displayed incomplete drillholes. Prey effectiveness for the Corbulidae was 0.20 (for species that included incomplete holes; when all corbulid species are included, prey effectiveness equals 0.167 ). Other families with abundant drillholes and high prey effectiveness include the Carditidae and Kelliellidae.
TABLE 7-Data from Tables 6 and 10, summarized by family. (Only families with infaunal species listed.) Also shown, for each family, is the number of species with incomplete holes. (Species occurring at more than one stratigraphic level are counted more than once.) Families listed in order of prey effectiveness.

\begin{tabular}{|c|c|c|c|c|}
\hline Family & C.D. & Inc. & P.E. & $\begin{array}{l}\text { No. } \\
\text { of } \\
\text { spe } \\
\text { cies }\end{array}$ \\
\hline \multicolumn{5}{|l|}{ Bivalves } \\
\hline Glycymeridae & 0 & 1 & 1.0 & 1 \\
\hline Mesodesmatidae & 1 & 1 & 0.5 & 1 \\
\hline Veneridae & 5 & 3 & 0.375 & 2 \\
\hline Crassatellidae & 14 & 6 & 0.300 & 3 \\
\hline Limopsidae & 17 & 7 & 0.292 & 3 \\
\hline Kellielidae & 200 & 71 & 0.262 & 2 \\
\hline Ungulinidae & 3 & 1 & 0.25 & 1 \\
\hline Carditidae & 38 & 11 & 0.224 & 5 \\
\hline Nuculanidae & 21 & 6 & 0.222 & 4 \\
\hline Corbulidae & 688 & 167 & 0.195 & 24 \\
\hline Cucullaeidae & 12 & 2 & 0.143 & 2 \\
\hline Astartidae & 42 & 5 & 0.106 & 3 \\
\hline Arcidae & 36 & 4 & 0.1 & 2 \\
\hline Mactridae & 69 & 6 & 0.08 & 2 \\
\hline Lucinidae & 307 & 11 & 0.035 & 3 \\
\hline Noetidae & 311 & 10 & 0.031 & 4 \\
\hline Total for 16 families & 1764 & 312 & 0.150 & 62 \\
\hline \multicolumn{5}{|l|}{ Gastropods } \\
\hline Strombidae & 3 & 2 & 0.40 & 1 \\
\hline Retusidae & 5 & 1 & 0.167 & 1 \\
\hline Naticidae & 67 & 10 & 0.130 & 4 \\
\hline Turritellidae & 283 & 10 & 0.034 & 5 \\
\hline Buccinidae & 211 & 1 & 0.005 & 1 \\
\hline Total for 5 families & 569 & 24 & 0.040 & 12 \\
\hline
\end{tabular}


TABLE 8-Numbers of complete (C.D.) and incomplete (inc.) drillholes and prey effectiveness (P.E. = number of incomplete holes: total attempted holes) for all bivalves and for infaunal bivalves within each level.

\begin{tabular}{lrrrrrr}
\hline \hline & \multicolumn{3}{c}{ All bivalves } & \multicolumn{3}{c}{ Infaunal bivalves } \\
\cline { 2 - 7 } \multicolumn{1}{c}{ Level } & C.D. & Inc. & P.E. & C.D. & Inc. & P.E. \\
\hline Ripley & 174 & 10 & 0.054 & 172 & 10 & 0.055 \\
Providence & 62 & 1 & 0.016 & 62 & 1 & 0.016 \\
Corsicana & 8 & 3 & 0.273 & 8 & 1 & 0.111 \\
Kincaid & 18 & 1 & 0.053 & 18 & 1 & 0.053 \\
Brightseat & 285 & 27 & 0.087 & 284 & 27 & 0.087 \\
Matthews Landing & 13 & 4 & 0.235 & 13 & 4 & 0.235 \\
Bells Landing & 0 & 1 & 1.0 & 0 & 1 & 1.0 \\
Bashi & 233 & 11 & 0.045 & 233 & 11 & 0.045 \\
Cook Mountain & 721 & 48 & 0.062 & 668 & 39 & 0.055 \\
Gosport & 17 & 2 & 0.105 & 16 & 2 & 0.111 \\
Moodys Branch & 587 & 127 & 0.178 & 583 & 127 & 0.179 \\
Red Bluff & 258 & 60 & 0.189 & 258 & 55 & 0.176 \\
Mint Spring & 163 & 25 & 0.133 & 158 & 25 & 0.137 \\
Byram & 46 & 8 & 0.148 & 46 & 8 & 0.148 \\
Summary & 2585 & 328 & 0.113 & 2519 & 312 & 0.110 \\
\hline
\end{tabular}

TABLE 9-Numbers and percentages of all gastropod species, successfully drilled gastropod species, infaunal gastropod species (inf. sp.), and infaunal successfully drilled gastropod species (inf. dr. sp.) bearing incomplete and multiple holes.

\begin{tabular}{|c|c|c|c|c|c|c|c|c|c|c|}
\hline \multirow[b]{2}{*}{ Level } & \multicolumn{4}{|c|}{ All species } & \multicolumn{2}{|c|}{ Drilled sp. } & \multicolumn{2}{|c|}{ Inf. sp. } & \multicolumn{2}{|c|}{ Inf. dr. sp. } \\
\hline & $\begin{array}{l}\# \text { w/ } \\
\text { inc. }\end{array}$ & $\begin{array}{l}\# \text { w/ } \\
\text { mul. }\end{array}$ & $\begin{array}{l}\% \mathrm{w} / \\
\text { inc. }\end{array}$ & $\begin{array}{l}\% \mathrm{w} / \\
\text { mul. }\end{array}$ & $\begin{array}{l}\% \mathrm{w} / \\
\text { inc. }\end{array}$ & $\begin{array}{l}\% \mathrm{w} / \\
\text { mul. }\end{array}$ & $\begin{array}{l}\% \mathrm{w} / \\
\text { inc. }\end{array}$ & $\begin{array}{l}\% \mathrm{w} / \\
\text { mul. }\end{array}$ & $\begin{array}{l}\% \mathrm{w} / \\
\text { inc. }\end{array}$ & $\begin{array}{l}\% \mathrm{w} / \\
\text { mul. }\end{array}$ \\
\hline Ripley & 1 & 2 & 3.4 & 6.9 & 6.7 & 13.3 & 0 & 0 & 0 & 0 \\
\hline Providence & 0 & 0 & 0 & 0 & 0 & 0 & 0 & 0 & 0 & 0 \\
\hline Brightseat & 0 & 0 & 0 & 0 & 0 & 0 & 0 & 0 & 0 & 0 \\
\hline Matthews Landing & 0 & 5 & 0 & 25.0 & 0 & 50.0 & 0 & 20.0 & 0 & 25.0 \\
\hline Bells Landing & 1 & 1 & 3.8 & 3.8 & 10.0 & 10.0 & 7.1 & 7.1 & 14.3 & 14.3 \\
\hline Bashi & 1 & 1 & 3.1 & 3.1 & 7.1 & 7.1 & 0 & 8.3 & 0 & 16.7 \\
\hline Cook Mountain & 12 & 8 & 20.3 & 13.6 & 46.1 & 30.8 & 28.6 & 17.9 & 57.1 & 35.7 \\
\hline Gosport & 1 & 1 & 4.3 & 4.3 & 20.0 & 20.0 & 10.0 & 10.0 & 20.0 & 20.0 \\
\hline Moodys Branch & 2 & 4 & 4.3 & 8.6 & 10.5 & 21.1 & 7.7 & 7.7 & 12.5 & 12.5 \\
\hline Red Bluff & 2 & 2 & 5.1 & 5.1 & 22.2 & 22.2 & 7.7 & 7.7 & 50.0 & 50.0 \\
\hline Mint Spring & 3 & 4 & 5.9 & 7.8 & 11.1 & 14.8 & 0 & 0 & 0 & 0 \\
\hline Byram & 0 & 2 & 0 & 8.0 & 0 & 16.7 & 0 & 11.1 & 0 & 20.0 \\
\hline
\end{tabular}

Besides considering effectiveness of individual prey taxa, we computed the effectiveness of all bivalve prey within each formation (Table 8). Prey effectiveness was 0.11 for the entire Cretaceous through Oligocene bivalve data set (both for infaunal and all bivalves). Prey effectiveness for the Cretaceous and Paleocene was generally low (less than 0.1 ), with the exception of levels that contained few drilled specimens. Prey effectiveness remained low in the Eocene Bashi and Cook Mountain Levels (0.04-0.06), but was much higher for upper Eocene and Oligocene samples (0.13$0.19)$. In general, prey effectiveness in the Paleocene was not significantly higher than in the Cretaceous $\left(\chi^{2}=3.37\right)$, but in the Oligocene it was higher than in the Cretaceous $\left(\chi^{2}=19.42\right)$, Paleocene $\left(\chi^{2}=9.21\right)$, and Eocene $\left(\chi^{2}=13.51\right)$. Spearman's rank correlation between stratigraphic order and prey effectiveness (infaunal prey only) of a formation is statistically significant $(0.6168, \mathrm{P}<0.05)$.

A much lower incidence of incomplete drillholes occurred in gastropods than in bivalves (Table 9). Incomplete drillholes are especially rare in Cretaceous and Paleocene samples; only two of 105 gastropod species (4 incomplete drillholes, total) examined from these levels contained incomplete holes. For most Eocene and Oligocene samples, about $3-6 \%$ of the species $(0-10 \%$ of the infaunal species) 
TABLE 10-Numbers of complete (C.D.) and incomplete (inc.) drillholes and prey effectiveness (P.E. = number of incomplete holes: total attempted holes) for gastropod species that exhibited incomplete drilling.

\begin{tabular}{llrrl}
\hline \hline \multicolumn{1}{c}{ Level } & \multicolumn{1}{c}{ Species } & C.D. & Inc. & P.E. \\
\hline Ripley & Creonella triplicata & 3 & 1 & 0.25 \\
Bells Landing & Mesalia alabamiensis tetradeiras & 222 & 3 & 0.013 \\
Bashi & Eopleurotoma cf. E. sayi & 1 & 1 & 0.5 \\
Cook Mountain & Turritella carinata & 7 & 2 & 0.222 \\
& Turritella nasuta & 21 & 2 & 0.087 \\
& Calyptraphorus velatus & 3 & 2 & 0.40 \\
& Hipponix pygmaeus & 4 & 2 & 0.333 \\
& Calyptraea aperta & 2 & 1 & 0.333 \\
& Neverita limula & 11 & 7 & 0.389 \\
& Polinices aratus & 48 & 1 & 0.020 \\
& Naticid & 3 & 1 & 0.25 \\
& Buccitriton texanum & 211 & 1 & 0.005 \\
Gosport & Turrid & 0 & 2 & 1.0 \\
Moodys texana & 1 & 1 & 0.5 \\
& Retusa (Cylichna) galba & 5 & 1 & 0.167 \\
Red Bluff & Mesalia vetusta & 9 & 2 & 0.182 \\
& Hipponix pygmaea & 40 & 22 & 0.355 \\
Mint Spring & Euspira jacksonensis & 5 & 1 & 0.167 \\
& Capulus americanus & 2 & 3 & 0.6 \\
Byram & Turritella aff. T. premimetes & 24 & 1 & 0.04 \\
& Tropisurcula caseyi & 0 & $1 ?$ & 0.667 \\
& Vexillum lintoidea & 3 & 2 & 0.333 \\
& Syntomodrillia tantula & 3 & 1 & 0.273 \\
& Pyramidella (Voluspa) leafensis & 11 & 3 & 1.0 \\
\hline
\end{tabular}

TABLE 11-Numbers of complete (C.D.) and incomplete (inc.) drillholes and prey effectiveness (P.E. = number of incomplete holes: total attempted holes) for all gastropods and for infaunal gastropods within each level.

\begin{tabular}{|c|c|c|c|c|c|c|}
\hline \multirow[b]{2}{*}{ Level } & \multicolumn{3}{|c|}{ All gastropods } & \multicolumn{3}{|c|}{ Infaunal gastropods } \\
\hline & C.D. & Inc. & P.E. & C.D. & Inc. & P.E. \\
\hline Ripley & 90 & 1 & 0.011 & 48 & 0 & 0 \\
\hline Providence & 31 & 0 & 0 & 26 & 0 & 0 \\
\hline Brightseat & 156 & 0 & 0 & 133 & 0 & 0 \\
\hline Matthews Landing & 138 & 0 & 0 & 88 & 0 & 0 \\
\hline Bells Landing & 261 & 3 & 0.011 & 253 & 3 & 0.012 \\
\hline Bashi & 55 & 1 & 0.018 & 39 & 0 & 0 \\
\hline Cook Mountain & 447 & 23 & 0.049 & 426 & 17 & 0.038 \\
\hline Gosport & 15 & 2 & 0.118 & 15 & 2 & 0.118 \\
\hline Moodys Branch & 104 & 36 & 0.257 & 48 & 1 & 0.020 \\
\hline Red Bluff & 39 & 1 & 0.025 & 23 & 1 & 0.042 \\
\hline Mint Spring & 107 & 6 & 0.053 & 61 & 0 & 0 \\
\hline Byram & 31 & 5 & 0.139 & 14 & 0 & 0 \\
\hline Summary & 1474 & 78 & 0.050 & 1100 & 24 & 0.021 \\
\hline
\end{tabular}

TABLE 12-Numbers of attempted drillholes (tot.), those occurring in multiply bored valves (mult.) and the frequency of multiple drillholes $(\mathrm{M} / \mathrm{T}=$ number of holes in multiply drilled valves: total attempted holes) for all bivalves and for infaunal bivalves within each level.

\begin{tabular}{|c|c|c|c|c|c|c|}
\hline \multirow[b]{2}{*}{ Level } & \multicolumn{3}{|c|}{ All bivalves } & \multicolumn{3}{|c|}{ Infaunal bivalves } \\
\hline & Tot. & Mult. & $\mathrm{M} / \mathrm{T}$ & Tot. & Mult. & $\mathrm{M} / \mathrm{T}$ \\
\hline Ripley & 184 & 0 & 0 & 182 & 0 & 0 \\
\hline Providence & 63 & 0 & 0 & 63 & 0 & 0 \\
\hline Corsicana & 11 & 0 & 0 & 9 & 0 & 0 \\
\hline Kincaid & 19 & 2 & 0.105 & 19 & 2 & 0.105 \\
\hline Brightseat & 312 & 8 & 0.026 & 311 & 8 & 0.026 \\
\hline Matthews Landing & 17 & 2 & 0.118 & 17 & 2 & 0.118 \\
\hline Bells Landing & 1 & 0 & 0 & 1 & 0 & 0 \\
\hline Bashi & 244 & 16 & 0.066 & 244 & 16 & 0.066 \\
\hline Cook Mountain & 769 & 30 & 0.039 & 707 & 16 & 0.023 \\
\hline Gosport & 19 & 2 & 0.105 & 18 & 2 & 0.111 \\
\hline Moodys Branch & 714 & 64 & 0.090 & 710 & 64 & 0.090 \\
\hline Red Bluff & 318 & 49 & 0.154 & 313 & 45 & 0.144 \\
\hline Mint Spring & 188 & 29 & 0.154 & 183 & 29 & 0.158 \\
\hline Byram & 54 & 4 & 0.074 & 54 & 4 & 0.074 \\
\hline Summary & 2913 & 206 & 0.071 & 2831 & 188 & 0.066 \\
\hline
\end{tabular}


TABLE 13-Numbers of attempted drillholes (tot.), those occurring in multiply bored valves (mul.), and the frequency of multiple drillholes $(\mathrm{M} / \mathrm{T}=$ number of holes in multiply drilled valves:total attempted holes) for bivalve species that exhibited multiply drilled valves.

\begin{tabular}{|c|c|c|c|c|}
\hline Level & Species & Tot. & Mul. & $\mathrm{M} / \mathrm{T}$ \\
\hline Kincaid & Striarca sp. & 2 & 2 & 1.0 \\
\hline \multirow[t]{3}{*}{ Brightseat } & Vokesula aldrichi & 35 & 4 & 0.114 \\
\hline & Venericardia sp. & 39 & 2 & 0.051 \\
\hline & Phacoides sp. & 95 & 2 & 0.021 \\
\hline Matthews Landing & Corbula subcompressa & 4 & 2 & 0.5 \\
\hline \multirow[t]{3}{*}{ Bashi } & Venericardia horatiana & 134 & 2 & 0.015 \\
\hline & Corbula subengonata & 39 & 8 & 0.205 \\
\hline & Vokesula aldrichi & 51 & 6 & 0.118 \\
\hline \multirow[t]{7}{*}{ Cook Mountain } & Pachecoa decisa & 271 & 2 & 0.007 \\
\hline & Pachecoa declivis & 12 & 2 & 0.167 \\
\hline & Cubitostrea sellaeformis & 60 & 14 & 0.233 \\
\hline & Lucina pomilia & 153 & 2 & 0.013 \\
\hline & Corbula cf. C. alabamiensis & 6 & 2 & 0.333 \\
\hline & Corbula extenuata & 45 & 2 & 0.044 \\
\hline & Caryocorbula deusseni & 38 & 6 & 0.158 \\
\hline Gosport & cf. Caestocorbula murchisonii & 3 & 2 & 0.667 \\
\hline \multirow[t]{12}{*}{ Moodys Branch } & Caestocorbula wailesiana & 82 & 17 & 0.207 \\
\hline & Caryocorbula densata & 35 & 8 & 0.229 \\
\hline & Venericardia diversidensata & 21 & 2 & 0.095 \\
\hline & Alveinus minutus & 225 & 9 & 0.04 \\
\hline & Limopsis radiata & 10 & 2 & 0.2 \\
\hline & Lucina subcurta & 104 & 4 & 0.038 \\
\hline & Lucina curta & 61 & 2 & 0.033 \\
\hline & Bathytormus flexurus & 9 & 2 & 0.222 \\
\hline & Spisula jacksonensis & 41 & 2 & 0.049 \\
\hline & Kelliella boettgeri & 46 & 10 & 0.217 \\
\hline & Verticordia cossmani & 4 & 2 & 0.5 \\
\hline & Nucula spheniopsis & 18 & 4 & 0.222 \\
\hline \multirow[t]{5}{*}{ Red Bluff } & Eburneopecten subminutus & 5 & 4 & 0.80 \\
\hline & Timothynus turgida? & 4 & 4 & 1.0 \\
\hline & Astarte triangulata & 45 & 2 & 0.044 \\
\hline & Corbula (V.) rufaripa & 214 & 29 & 0.136 \\
\hline & Corbula (Caryocorbula) engonata & 12 & 10 & 0.833 \\
\hline \multirow[t]{2}{*}{ Mint Spring } & Corbula (Caryocorbula) engonata & 19 & 2 & 0.105 \\
\hline & Corbula (Varicorbula) laqueata & 98 & 27 & 0.276 \\
\hline Byram & Corbula (Varicorbula) laqueata & 29 & 4 & 0.137 \\
\hline
\end{tabular}

displayed incomplete drillholes. (The large Cook Mountain sample is the anomaly, with $20 \%$ of all gastropod species and $28 \%$ of infaunal species exhibiting incomplete holes.) When the number of species with incomplete holes is compared to that of successfully drilled species, the disparity between Cretaceous-Paleocene and Eocene-Oligocene levels remains. However, there is a significant correlation between the percent of gastropod species with incomplete holes and number of gastropod specimens within a stratigraphic level $(\mathrm{r}=0.7459, \mathrm{P}<0.01)$. The fewer numbers of species with incomplete drillholes in older samples may be due in part to sampling effects.

Table 10 lists gastropod species that exhibited incomplete drillholes, along with data on prey effectiveness; Table 7 provides a summary by family. Five infaunal families displayed incomplete holes, but only the Turritellidae and Naticidae had as many as ten incomplete holes. Prey effectiveness was 0.03 and 0.13 for the two families, respectively. (These values include only species containing incomplete drillholes; the value for all turritellid species is 0.013.)

The effectiveness of gastropod prey was much less than for bivalve prey (Table 11). Considering all levels combined, only 78 of 1552 attempted drillholes were incomplete, yielding a prey effectiveness of 0.05 ( 0.02 for infaunal prey). Prey effectiveness in the Cretaceous and Paleocene was very low ( 0 for all but the Ripley and Bells Landing, which had a prey effectiveness of 0.01 ). Prey effectiveness was higher in the Eocene and Oligocene, particularly in the Gosport, Moodys Branch, and Byram Formations. A 
TABLE 14-Data from Tables 13 and 16, summarized by family. (Only families with infaunal species listed.) Also shown, for each family, is the number of species with multiply bored shells. (Species occurring at more than one level are counted more than once.) Families listed in order of frequency of multiple holes.

\begin{tabular}{|c|c|c|c|c|}
\hline Family & Tot. & Mul. & $\mathrm{M} / \mathrm{T}$ & $\begin{array}{l}\text { No. } \\
\text { of } \\
\text { spe- } \\
\text { cies }\end{array}$ \\
\hline \multicolumn{5}{|l|}{ Bivalves } \\
\hline Ungulinidae & 4 & 4 & 1 & 1 \\
\hline Verticordiidae & 4 & 2 & 0.5 & 1 \\
\hline Nuculidae & 18 & 4 & 0.222 & 1 \\
\hline Crassatellidae & 9 & 2 & 0.222 & 1 \\
\hline Limopsidae & 10 & 2 & 0.2 & 1 \\
\hline Corbulidae & 710 & 129 & 0.182 & 15 \\
\hline Kelliellidae & 271 & 19 & 0.070 & 2 \\
\hline Mactridae & 41 & 2 & 0.049 & 1 \\
\hline Astartidae & 45 & 2 & 0.044 & 1 \\
\hline Carditidae & 194 & 6 & 0.031 & 3 \\
\hline Lucinidae & 413 & 10 & 0.024 & 4 \\
\hline Noetidae & 285 & 6 & 0.021 & 3 \\
\hline Total for 12 families & 2004 & 188 & 0.094 & 34 \\
\hline \multicolumn{5}{|l|}{ Gastropods } \\
\hline Strombidae & 5 & 3 & 0.60 & 1 \\
\hline Terebridae & 5 & 2 & 0.40 & 1 \\
\hline Vermetidae & 14 & 2 & 0.142 & 1 \\
\hline Turritellidae & 543 & 76 & 0.140 & 9 \\
\hline Buccinidae & 212 & 6 & 0.028 & 1 \\
\hline Total for 5 families & 779 & 89 & 0.114 & 13 \\
\hline
\end{tabular}

significant rank correlation $(0.8531, \mathrm{P}<0.01)$ exists between stratigraphic order of levels and prey effectiveness, suggesting a temporal increase in prey effectiveness.

Multiple drillholes were less common than incomplete holes, but were prominent for certain levels and taxa (Table 5). No multiply bored prey were noted in any of the Cretaceous samples of bivalves. With the exception of the Bells Landing, which contains relatively few bivalves, multiply bored species were present in all the Paleocene through Oligocene samples. The percent of species with multiple boreholes ranged from $2-23 \%$, with high percentages occurring in the Matthews Landing, Bashi, Moodys Branch, and Red Bluff levels. The incidence of multiply bored species may be related to sampling, for the correlation between percent of species with multiple holes and number of specimens in a unit is significant $(\mathrm{r}=0.5425, \mathrm{P}<0.05)$.

Considering all fourteen levels, about $7 \%$ of all drillholes occurred in multiply bored valves (Table 12). A significant rank correlation occurs between stratigraphic order of a level and the percent of drillholes occurring in multiply bored valves $(0.6964, \mathrm{P}<0.01)$. Multiple drillholes thus appear to have become more common through time, with $0,3 \%, 6 \%$, and $15 \%$ of drillholes occurring in multiply
TABLE 15-Numbers of attempted drillholes (tot.), those occurring in multiply bored shells (mult.) and the frequency of multiple drillholes $(M / T=$ number of holes in multiply drilled shells: total attempted holes) for all gastropods and for infaunal gastropods within each level.

\begin{tabular}{|c|c|c|c|c|c|c|}
\hline \multirow[b]{2}{*}{ Level } & \multicolumn{3}{|c|}{ All gastropods } & \multicolumn{3}{|c|}{ Infaunal gastropods } \\
\hline & Tot. & Mult. & $\mathrm{M} / \mathrm{T}$ & Tot. & Mult. & $\mathrm{M} / \mathrm{T}$ \\
\hline Ripley & 91 & 4 & 0.044 & 48 & 0 & 0 \\
\hline Providence & 31 & 0 & 0 & 26 & 0 & 0 \\
\hline Brightseat & 156 & 0 & 0 & 133 & 0 & 0 \\
\hline Matthews Landing & 138 & 47 & 0.341 & 88 & 31 & 0.352 \\
\hline Bells Landing & 264 & 4 & 0.015 & 256 & 4 & 0.016 \\
\hline Bashi & 56 & 2 & 0.036 & 39 & 2 & 0.051 \\
\hline Cook Mountain & 470 & 48 & 0.102 & 443 & 39 & 0.088 \\
\hline Gosport & 17 & 2 & 0.118 & 17 & 2 & 0.118 \\
\hline Moodys Branch & 140 & 25 & 0.179 & 49 & 2 & 0.041 \\
\hline Red Bluff & 40 & 9 & 0.225 & 24 & 5 & 0.208 \\
\hline Mint Spring & 113 & 18 & 0.159 & 61 & 0 & 0 \\
\hline Byram & 36 & 7 & 0.194 & 14 & 2 & 0.143 \\
\hline Summary & 1552 & 166 & 0.107 & 1124 & 89 & 0.079 \\
\hline
\end{tabular}

bored valves for the Cretaceous, Paleocene, Eocene, and Oligocene, respectively. Chi-squared tests indicate that the value for each of these epochs is significantly greater than that for the preceding epoch, with the overall increase being highly significant $\left(\chi^{2}=36.26,1\right.$ d.f.). The pattern is the same if only infaunal bivalves are considered.

Table 13 lists the bivalve species that included multiply bored shells. Twelve infaunal bivalve families are represented (Table 14), though the Ungulinidae, Verticordiidae, Crassatellidae, and Limopsidae are represented by ten or fewer drillholes each. The incidence of multiple holes for the other eight families ranged from about $2-4 \%$, with the exception of the Corbulidae and Nuculidae. Only one nuculid species exhibited multiple boreholes (4 of 18 boreholes were in multiply bored valves). However, 15 corbulid species displayed multiple boreholes; 129 drillholes (18\%) occurred in multiply bored shells (including species with only singly bored valves, the value is still $15 \%$ ).

In general, fewer gastropod than bivalve specimens exhibited multiple drillholes. Multiply drilled gastropod species were most common in the Matthews Landing, Cook Mountain, Moodys Branch, and Oligocene levels (Table 9 ). The occurrence of multiply bored species is not simply related to sampling, as the correlation between sample size and number of species with multiply bored shells at a stratigraphic level is nonsignificant $(\mathrm{r}=0.3019,12$ d.f. $)$.

There is some evidence for a temporal increase in the incidence of multiple drillholes in gastropods. For the twelve levels from which gastropod data were available, $11 \%$ of all drillholes occurred in multiply bored shells (Table 15). Only $3 \%$ of Cretaceous drillholes occurred in multiply bored shells; the values for the Paleocene, Eocene, and Oligocene are $9 \%, 11 \%$, and $18 \%$, respectively. The differences between Cretaceous and Paleocene levels $\left(\chi^{2}=\right.$ 
TABLE 16-Numbers of attempted drillholes (tot.), those occurring in multiply bored shells (mul.), and the frequency of multiple drillholes ( $\mathrm{M} / \mathrm{T}=$ number of holes in multiply drilled shells: total attempted holes) for gastropod species that exhibited multiply drilled shells.

\begin{tabular}{|c|c|c|c|c|}
\hline Level & Species & Tot. & Mul. & $\mathrm{M} / \mathrm{T}$ \\
\hline \multirow[t]{2}{*}{ Ripley } & Laxispira monilifera & 14 & 2 & 0.143 \\
\hline & Creonella triplicata & 4 & 2 & 0.5 \\
\hline \multirow[t]{5}{*}{ Matthews Landing } & Rissoina alabamensis & 30 & 10 & 0.333 \\
\hline & Turritella aldrichi & 93 & 31 & 0.333 \\
\hline & Fasciolaridae & 6 & 2 & 0.333 \\
\hline & Cancellaridae & 6 & 2 & 0.333 \\
\hline & Microdrillia sp. & 11 & 2 & 0.182 \\
\hline Bells Landing & Mesalia alabamiensis tetradeiras & 225 & 4 & 0.018 \\
\hline Bashi & Turritella gilberti & 28 & 2 & 0.071 \\
\hline \multirow[t]{8}{*}{ Cook Mountain } & Turritella carinata & 9 & 6 & 0.667 \\
\hline & Turritella nasuta & 23 & 4 & 0.174 \\
\hline & Turritella sp. & 103 & 20 & 0.194 \\
\hline & Calyptraphorus velatus & 5 & 3 & 0.6 \\
\hline & Hipponix pygmaeus & 6 & 5 & 0.833 \\
\hline & Buccitriton texanum & 212 & 6 & 0.028 \\
\hline & Eucheilodon reticularis & 6 & 2 & 0.333 \\
\hline & Hesperiturris nodocarinatus & 3 & 2 & 0.667 \\
\hline Gosport & Mesalia vetusta & 11 & 2 & 0.182 \\
\hline \multirow[t]{4}{*}{ Moodys Branch } & Pyramidella meyeri & 2 & 2 & 1.0 \\
\hline & Turritella alveata & 26 & 2 & 0.077 \\
\hline & Hipponix pygmaea & 72 & 18 & 0.25 \\
\hline & Capulus americanus & 5 & 3 & 0.6 \\
\hline \multirow[t]{2}{*}{ Red Bluff } & Turritella aff. T. premimetes & 25 & 5 & 0.20 \\
\hline & Syntomodrillia colorubra & 7 & 4 & 0.571 \\
\hline \multirow[t]{4}{*}{ Mint Spring } & Tritiaria falsus & 3 & 3 & 1.0 \\
\hline & Vexillum lintoidea & 5 & 3 & 0.6 \\
\hline & Pyramidella (Voluspa) leafensis & 14 & 7 & 0.5 \\
\hline & Eulimella clearyensis & 5 & 5 & 1.0 \\
\hline \multirow[t]{2}{*}{ Byram } & Terebra sp. & 5 & 2 & 0.4 \\
\hline & Odostomia byramensis & 5 & 5 & 1.0 \\
\hline
\end{tabular}

4.08) and Eocene and Oligocene levels $\left(\chi^{2}=4.50\right)$ are statistically significant. Spearman's rank correlation between stratigraphic order of a level and percent of drillholes occurring in multiply bored shells also is significant $(0.6276$, $\mathrm{P}<0.05)$.

Table 16 lists the gastropod species that experienced multiple boring. Infaunal species represent five different families (Table 14). Multiple drillholes were particularly common in the Turritellidae. Of the 543 drillholes on turritellid species with multiple drillholes, $14 \%$ were in multiply bored shells. (When species with only singly bored shells are included, the value is $6 \%$.)

\section{HEAVILY PREYED TAXA THROUGH TIME}

Extant naticids are selective with respect to prey taxon, as were their counterparts studied from various, primarily Neogene, fossil assemblages (Kitchell, 1982; Hoffman and Martinell, 1984; Kitchell et al., 1981; Kelley, 1988, 1991). Taxon-selective predation also is evident in our Cretaceous through Oligocene data set.
As expected, based on the life mode of the predator, infaunal molluscs are the most commonly drilled prey; of this group, some species are drilled in substantially greater proportions than expected based on their representation in the fauna. Individuals of the family Turritellidae, for example, are particularly abundant in Paleocene assemblages. In the Brightseat Formation, Haustator gnoma comprises $21 \%$ of the fauna and $32 \%$ of the drilled individuals. In the Matthews Landing Member, Turritella aldrichi (28\% of the fauna, $44 \%$ of drilled individuals) and, in the Bells Landing Member, Mesalia alabamiensis tetradeiras (45\% of fauna, $67 \%$ of drilled) conform to this pattern.

Other commonly attacked families are the Lucinidae and Corbulidae. Species of these families are often drilled at greater than average frequencies, whether or not they are the most abundant taxa. All three families are infaunal suspension feeders and sluggish burrowers. Other frequently drilled taxa are the Arcidae, Noetiidae, and Carditidae, and the Crassatellacea. All are nonsiphonate, infaunal suspension feeding bivalves, and extremely slow 
burrowers. Certain species of other families, such as the Veneridae or Buccinidae, may be drilled substantially in a particular environment within a formation, but not as consistently through time as the groups mentioned above.

Infaunal species represented by more than 100 individuals in any formation but with lower than average drilling frequencies include Nucula, Hilgardia, Yoldia (all deposit-feeding bivalves), Limopsis (nonsiphonate suspension feeding bivalve), Spisula, Alveinus, and Kelliella (all three siphonate suspension feeding bivalves). Sander and Lalli (1982) noted the conspicuous lack of drillholes in $\mathrm{Nucu}$ lana and Limopsis in modern molluscan assemblages from Barbados, citing the small size of these two taxa as a possible deterrent. In our data set these genera are comparable in size to heavily drilled taxa, so another explanation seems necessary. Limopsis resembles many lucinids in size, but Limopsis has a thicker shell, probably increasing its costbenefit ratio. It also has a hairy periostracum, which may help protect it (Vermeij, pers. comm.). Nuculana (and most members of the Nuculanidae) have conspicuously thin shells, but they are active burrowers and thus more likely to avoid capture. Alveinus and Kelliella, however, are very small.

We have not yet examined whether the dynamics of prey selectivity, as recorded in our database, changed through time. Ongoing cost-benefit analyses will indicate whether the degree of prey selectivity, or the criteria used in prey selection, changed during the Cretaceous through Oligocene.

\section{DISCUSSION}

Our data show a dramatic and abrupt increase in overal drilling frequency in the middle Danian (lower Paleocene) Brightseat Formation. We cannot be sure if the low incidence of drilling in the early Danian Kincaid Formation is real or an artifact of preservation and very low sample size. In any case, our data suggest that naticid drilling frequencies rose relatively abruptly and soon after the Cretaceous-Tertiary extinction. Hazel et al. (1984) determined that the calcareous nannofossil assemblage of the Brightseat Formation is representative of the Chiasmolithus danicus zone (NP3, middle Danian stage). Using the Graphic Correlation Technique, Hazel et al. (1984) calculated that the duration of the NP3 zone was from about $65.4 \mathrm{Ma}$ to about $63.8 \mathrm{Ma}$. This would place the dramatic increase in drilling frequencies to within one to three million years of the Cretaceous-Tertiary boundary.

This high frequency of drilling was maintained until the late Eocene, when it dropped to Cretaceous levels, and then rose again in the Oligocene to a moderate level. The Moodys Branch Formation, characterized by a very low drilling frequency, represents the largest sample size $(14,310$ specimens), so this data point is robust. Apparently the breakthrough that enabled the naticids to achieve high drilling frequencies in the Paleocene only raised the ceiling on those predation intensities.

As suggested by Kitchell (1990) and by Vermeij (1987), it is difficult to generate simple predictions from the hy- pothesis of escalation. One prediction may be that the frequency of drilling should have increased during the Cenozoic as a result of increasing biological hazards (Vermeij, 1987). Another interpretation suggests that, if escalation involving prey response to predators occurred, one might expect an initial increase in drilling frequency followed by stabilization of frequencies after parity was reached. This explanation was mentioned by Allmon et al. (1990), who suggested that turritelline antipredatory armor evolved quickly in the Cretaceous and remained relatively static through the Cenozoic. Our data on overall drilling frequencies show neither of these patterns. For the $30+$ million year time span from the Late Cretaceous into the early Oligocene, we see neither a progressive increase nor stabilization; we see statistically significant fluctuation.

Vermeij (1987) also suggested that escalation may be episodic; it should occur during periods of warming, transgression, and increased productivity, and be interrupted by extinction episodes. The stratigraphic distribution of our samples is still too spotty to correlate reliably with this complex of environmental variables. It is intriguing, however, that the drop in predation frequency in the late Eocene coincided with a diversity decrease for molluscs (Hansen, 1988) and an episode of general climatic cooling (Keller, 1983; Wolfe and Poore, 1982). There are also significant increases in drilling frequencies soon after extinction episodes at the Cretaceous-Tertiary and EoceneOligocene boundaries. We are in the process of obtaining additional samples to define better the record of naticid predation in the context of these environmental changes.

Escalation may predict a temporal increase in stereotypy of naticid behavior, because stereotypy in general promotes predator efficiency (Kelley, 1988). Thus far we have examined only stereotypy with respect to selection of drillhole site; future work will also examine selectivity of prey size and taxon, using cost-benefit analysis. There is no significant increase in stereotypy of drillhole site with time; naticids from all stratigraphic levels were selective of drillhole site for most prey taxa. Lack of drillhole site selectivity was common only in the Corbulidae. Although Anderson (1992) has suggested that corbulids are not unique with regard to patterns of drillhole site selectivity, the present study supports Kelley's (1988) contention that corbulids are often anomalous in terms of drillhole site and prey effectiveness.

Escalation of prey effectiveness is suggested by significant increases from the Cretaceous to the Oligocene in percentages of incomplete and multiple boreholes in the whole fauna. More direct information may be provided by groups that are particularly prone to naticid predation. The model of escalation may predict that a taxon that was heavily and consistently preyed upon for tens of millions of years would have responded either with escalation, restriction to refugia, or eventual extinction. The Turritellidae, Lucinidae, and Corbulidae usually suffered heavier than average predation when present in an assemblage in substantial numbers. The Turritellidae and Corbulidae show significant increases in percentages of incomplete and multiple boreholes from the Cretaceous through the 
Early Tertiary, but the increases are not consistent through time. The greatest increases for the Corbulidae occur from the Cretaceous to the Paleocene (coincident with the greatest increase in predation rate) and are less dramatic in the Eocene. The greatest increases for the Turritellidae occur between the Paleocene and Eocene. The Lucinidae do not show increases in prey effectiveness; they always have extremely small numbers of incomplete and multiple drills. Much work remains to be done on these predation-prone groups, however, as yet we do not have cost-benefit analyses of their component species nor do we understand their phylogenetic relationships.

\section{CONCLUSIONS}

1. Frequency of drilling by naticid gastropods shows neither a progressive increase nor increase followed by stabilization, as has been predicted based on the hypothesis of escalation. Drilling frequencies were relatively low in the Cretaceous, declined further at the Cretaceous-Tertiary boundary, rose dramatically above the boundary, and remained high until the late Eocene. Drilling declined significantly at the Eocene-Oligocene boundary and then increased during the Oligocene, but did not reach the high levels of the Paleocene and early Eocene.

2. Contrary to our predictions based on the hypothesis of escalation, no temporal trends occurred in behavioral stereotypy of naticids, as evidenced by drillhole site.

3. Frequency of incomplete drillholes and multiply bored shells increased both within entire faunas and individual lineages, indicating an increase in prey effectiveness consistent with the hypothesis of escalation.

4. Certain prey taxa, such as turritellids, corbulids, and lucinids, were consistently preferred by naticids. Preferred prey generally were sluggish burrowers, though not all such taxa were heavily drilled.

\section{ACKNOWLEDGMENTS}

We thank David Dockery for help in locating collecting sites and David Haasl for assistance in the field. David Haasl, Ben Farrell, Elizabeth Akins, and Ralph Lattimore assisted in data tabulation and analysis. Norman Sohl, Warren Blow, and Lauck Ward graciously provided access to additional samples. The manuscript benefitted from reviews by Geerat Vermeij, Warren Allmon, and an anonymous reviewer. Support for this study was provided by National Science Foundation grant EAR 8915725.

\section{REFERENCES}

Adegoke, O.S., and Tevesz, M.J.S., 1974, Gastropod predation patterns in the Eocene of Nigeria: Lethaia, v. 7, p. 17-24.

Allmon, W.D., NIEH, J.C., and NoRRIS, R.D., 1990, Drilling and peeling of turritelline gastropods since the Late Cretaceous: Palaeontology, v. 33, p. 595-611.

ANDERSON, L., 1992, Naticid gastropod predation on corbulid bivalves: Effects of physical factors, morphologic features, and statistical artifacts: PALAIOS, v. 7, p. 602-620.
BERG, C.J., and NishENKo, S., 1975, Stereotypy of predatory boring behavior of Pleistocene naticid gastropods: Paleobiology, v. 1, p. 258-260.

Boggs, C.H., Rice, J.A., Kitchell, J.A., and Post, W.M., 1984, Predation at a snail's pace: What's time to a gastropod?: Oecologia, v. 62 , p. $13-17$.

BRETSKY, S.S., 1976, Evolution and Classification of the Lucinidae (Mollusca; Bivalvia): Palaeontographica Americana, v. 8, no. 50, $337 \mathrm{p}$.

CARRIKER, M.R., 1981, Shell penetration and feeding by naticacean and muricacean predatory gastropods: A synthesis: Malacologia, v. 20 , p. $403-422$.

DeAngelis, D.L., Kitchell, J.A., and Post, W.M., in press, The nature of stasis and change: Potential coevolutionary dynamics, in STENSETH, N., ed., Coevolution of Ecosystems. Cambridge University Press, Cambridge.

DockerY, D.T., III, 1977, Mollusca of the Moodys Branch Formation, Mississippi: Mississippi Geological Survey Bulletin, v. 120, 212 p.

Dockery, D.T., III, 1982, Lower Oligocene Bivalvia of the Vicksburg Group in Mississippi: Mississippi Bureau of Geology Bulletin, v. $123,261 \mathrm{p}$.

Dudley, E.C., and VermeiJ, G.J., 1978, Predation in time and space: Drilling in the gastropod Turritella: Paleobiology, v. 4, p. 436441.

HANSEN, T.A., 1988, Early Tertiary radiation of marine molluscs and the long-term effects of the Cretaceous-Tertiary extinction: $\mathrm{Pa}$ leobiology, v. 14, p. 37-51.

Hazel, J.E., EdwarDS, L.E., and Bybell, L.M., 1984, Significant unconformities and the hiatuses represented by them in the $\mathrm{Pa}$ leogene of the Atlantic and Gulf Coastal Province, in SCHLEE, J.S., ed., Interregional Unconformities and Hydrocarbon Accumulation: American Association of Petroleum Geologists Memoir 36, p. 59-66.

Hoffman, A., and Martinell, J., 1984, Prey selection by naticid gastropods in the Pliocene of Emporda (Northeast Spain): Neues Jahrbuch für Geologie and Palaontologie Monatshefte, v. 1984, p. 393-399.

Kabat, A.R., and KoHn, A.J., 1986, Predation on early Pleistocene naticid gastropods in Fiji: Palaeogeography, Palaeoclimatology, Palaeoecology, v. 53, p. 255-269.

KELLER, G., 1983, Biochronology and paleoclimatic implications of Middle Eocene to Oligocene planktic foraminiferal faunas: Marine Micropaleontology, v. 7, p. 463-486.

$\rightarrow$ Kelley, P.H., 1988, Predation by Miocene gastropods of the Chesapeake Group: Stereotyped and predictable: PALAIOS, v. 3, p. 436-448.

KELLEY, P.H., 1989, Evolutionary trends within bivalve prey of Chesapeake Group naticid gastropods: Historical Biology, v. 2, p. 139156.

KeLley, P.H., 1991, Cannibalism by Chesapeake Group naticid gastropods: A predictable result of stereotyped predation: Journal of Paleontology, v. 65, p. $75-80$.

KITChell, J.A., 1982, Coevolution in a predator-prey system: Proceedings of the North American Paleontological Convention III, v. 2, p. 301-305.

KITCHELL, J.A., 1986, The evolution of predator-prey behavior: Naticid gastropods and their molluscan prey, in NITECKI, M., and KITCHELl, J.A., eds., Evolution of Animal Behavior: Paleontological and Field Approaches: Oxford University Press, Oxford, p. 88-110.

KITCHELL, J.A., 1990, The reciprocal interaction of organism and effective environment: Learning more about "and," in Ross, R.M., and Allmon, W.D., eds., Causes of Evolution: A Paleontological Perspective: University of Chicago Press, Chicago, p. 151-169.

Kitchell, J.A., BogGs, C.H., Kitchell, J.F., and RiCE, J.A., 1981, Prey selection by naticid gastropods: Experimental tests and application to the fossil record: Paleobiology, v. 7, p. 533-552.

Kitchell, J.A., Boggs, C.H., Rice, J.A., Kitchell, J.F., Hoffman, A., and Martinell, J., 1986, Anomalies in naticid predatory be- 
havior: A critique and experimental observations: Malacologia, v. 27, p. 291-298.

MACNEIL, F.S., and Dockery, D.T., III, 1984, Lower Oligocene Gastropoda, Scaphopoda, and Cephalopoda of the Vicksburg Group in Mississippi: Mississippi Bureau of Geology Bulletin, v. 124, $416 \mathrm{p}$.

Palmer, K.V.W., and BranN, D.C., 1965, 1966, Catalogue of the Paleocene and Eocene Mollusca of the Southern and Eastern United States: Bulletin of American Paleontology 48, v. 218, 1027 p.

Ross, R.W., and Allmon, W.D., eds., 1990, Causes of Evolution: A Paleontological Perspective: University of Chicago Press, Chicagc $\rightarrow$ $479 \mathrm{p}$.

SANDER, F., and Lalli, C.M., 1982, A comparative study of the mollusk communities on the shelf-slope margin of Barbados, West Indies: Veliger, v. 24, p. 309-318.

SoHL, N.F., 1969, The fossil record of shell boring by snails: American Zoologist, v. 9, p. 725-734.

STEPHENSON, L.W., 1941, The larger invertebrate fossils of the Navarro Group of Texas: University of Texas, Publication No. 4101, $641 \mathrm{p}$.
VAN VALEN, L., 1973, A new evolutionary law: Evolutionary Theory, v. 1, p. $1-30$.

VERMEIJ, G.J., 1983, Intimate associations and coevolution in the sea, in Futuyma, D.J., and Slatkin, M., eds., Coevolution: Sinauer Associates, Sunderland, Massachusetts, p. 311-327.

VERMEIJ, G.J., 1987, Evolution and Escalation: An Ecological History of Life: Princeton University Press, Princeton, $527 \mathrm{p}$.

VermeiJ, G.J., Dudley, E.C., and ZiPSER, E., 1989, Successful and unsuccessful drilling predation in Recent pelecypods: Veliger, v. 32 , p. 266-273.

VermeiJ, G.J., ZIPSER, E., and Dudley, E.C., 1980, Predation in time and space: Peeling and drilling in terebrid gastropods. Paleobiology, v. 6, p. 352-364.

WolfE, J.A., and PooRE, R.Z., 1982, Tertiary marine and nonmarine climatic trends, in BERGER, W.H., and CROWELl, J.C., eds., Climate in Earth History: National Academy of Sciences, Washington, D.C., p. 154-158.

ACCEPTED AUGUST 13, 1992 